\title{
Leasing and a Comparison between the Different Lease Rental Calculations in Iran
}

\author{
Ali Nemati (Corresponding author) \\ Faculty Member of Department of Accounting \\ Central Tehran Branch, Islamic Azad University, Tehran, Iran \\ Tel: 98-21-8434-1000 E-mail: anemati67@gmail.com \\ Yadollah Nemati \\ Central Tehran Branch, Islamic Azad University, Tehran, Iran \\ Tel: 98-91-7715-0425 E-mail: ynemati@yahoo.com
}

\author{
Received: January 5, 2012 \\ Accepted: February 7, $2012 \quad$ Published: April 16, 2012 \\ doi:10.5539/ijbm.v7n8p80 \\ URL: http://dx.doi.org/10.5539/ijbm.v7n8p80
}

\begin{abstract}
Leasing as a form financing besides loans, increasing capital and using different tools of monetary and financial markets has the main role in financing of goods so that this type of financing become the $2^{\text {nd }}$ after the direct loans for several years. Here, in this article leasing and its different types and phases of development briefly are defined and then lease rental calculation methods in Iran are focused on, their advantages and disadvantages are explained and compared and finally some suggestions are offered.

This article aims to analyze and compare the ordinary bank method and the PMT methods in terms offer of the calculation procedures involved in each. Banks in the past used the ordinary bank method while leasing companies used both methods. This situation has, however, changed recently and banks and leasing companies both use the PMT method these days. The other aim of this study is calculation of the stepped method. The problems that customers might have in paying back the finance in the beginning of the payback period has led to the offering of the stepped method to customers to solve their problem. Because of rise of income in the following years, this method will help these customers in such a way that they have to pay smaller initial installments and pay the larger ones in the following years when their income increases.
\end{abstract}

Keywords: Leasing, PMT method, Bank method, Lessee, Lessor

\section{Introduction}

Huge developments in supply and demand and production in the second half of the 20th century have led economic policy makers to make plans for the establishment of companies that can create credit methods to help the growth of the economy and industries. For this reason leasing industry has found a special place in global economy. Lease finance makes up to 1.8 percent of the private sector investments and lease revenues comprise 3 percent of the gross profit in developed countries. It can be, therefore, seen that leasing companies can contribute significantly to the economic and industrial development of countries (Miri, 2006).

Although leasing seems to be a new method of financing, its practical use dates back to centuries before. In BC 2000 Babylonians used some form of leasing boats and animals. One of the earliest theoretical descriptions of leasing was given in Roman legal texts. This is while financial leasing in its modern way dates back to 1900. The American company, MDP Botchier, wanted to make new investment to purchase new equipment in the 1950s but did not have the necessary finance for it. For this reason a new financial intermediary was established, United States Leasing Corporation, to solve this problem, thus provide the required finance. This method is widely used nowadays by companies which are short of finance. Leasing has thus experienced quick growth in the last decades and developed into an important financial method. This growth emanated mostly from the tax-related and financial advantages of leasing that existed in certain countries. Even in the absence of such advantages, economic studies show, in some periods, leasing has kept on growing at the same rate (Miri \& Habibi, 2007).

The first leasing company in Iran called "Iran Leasing Company" was established in 1975 by the French bank 
Credit Lion. A year later, 1976, the second leasing company was established called "Aria Leasing Company" by the French Society General and the Iranian bank Industry and Mine Bank (Miri \& Habibi, 2007).

Iran's leasing industry has changed a lot since then. Formal figures indicate that about 300 legal entities have been established in the leasing industry in Iran which offers a range of services. A wide range of assets including private and commercial vehicle, housing, medical equipment, office equipment, agricultural machineries, software, airplane, ship, etc. are transacted through leasing.

A major part of financial operations, investment and crediting is done through leasing in the world now. Leasing, as a result, stands second, after bank loans, in credit provision. The reminder of this paper is organized as follows. Section 2 provides literature review, section 3 describes the methodology, section 4 describes the calculation of the stepped method (up method - down method), and in Section 5 conclusions of study and suggestions are discussed.

\section{Literature Review}

The role that leasing plays in credit cycles and the undeniable positive effect it has had in creating the equilibrium in supply and demand and finally the logical balance it has created in payments in industrial and developing countries has led to a more solid position for leasing as one of the most important finance and credit provision sources in local and international economy (FASB, 2008).

\subsection{Different types of leasing}

\subsubsection{Finance lease (Capital lease; Full payout lease)}

Finance lease is described as a lease arrangement which increases beyond $75 \%$ of the asset's useful life. A bargain purchase is given to the lessee option which permits him to purchase the asset at less than fair market value. At the end of the lease term the ownership of the asset is conveyed to the lessee. The present value of the lease payments exceeds $90 \%$ of the total original cost of the equipment (Amembal, 2000; YearBook, 2007). All of the cost of its investment in the primary period from the lease rentals is recovered by the lesser in a finance lease.

\subsubsection{Operating lease (True lease; Short-term lease)}

An operating lease is considered as a lease arrangement in which the primary period is shorter than the useful life of the asset and the lessee obtains the use of an asset for a period shorter than the asset's useful life. It is a lease in which some services such as insurance and maintenance are given by the lessor. In this kind of lease the lessor does not rely on the lease rentals during the primary period to recover the full cost of its investment in the lease, but he looks forward to the residual value of the asset instead. An operating lease is usually considered by the lessees as a rental agreement (Amembal, 2000).

\subsubsection{Vendor lease (Sales aid lease)}

That is also known as vendor program or sales aid leasing, vendor leasing is given to the lessee as part of the sales package. Here lease finance is given by the manufacturer or dealer or a third party leasing company to the customer to stimulate sales and is therefore considered as an aid to selling (Williamson, Coopers \& Lybraud, 1992).

\subsubsection{Cross-border lease}

Cross-border leasing is defined as an arrangement hold between a lessor in one country and a lessee in another country.

\subsubsection{Sale and leaseback}

In this type of leasing arrangement the leasing company purchases an asset from a customer and leases it back immediately to the same customer. This provides the lessee with an immediate cash injection into its business (Amembal 2007; Miri \& Habibi, 2007).

\section{2 stages of Leasing Cycles}

The six stages of the leasing cycle are: Simple rentals, Simple finance leases, Creative finance leases, Operating leases, new product, and maturity.

\subsubsection{Simple rental}

Having come before the leasing product by centuries and even today, this is extremely competitive and vibrant in almost every country in the world. Rentals are characterized by their full-service nature and short-term that is usually less than twelve months. Almost invariably, at the end of the rental contract period, the equipment is 
returned by the user to the owner (Amembal, 2011).

\subsubsection{Simple Finance Lease}

Distinguished from the rental, this is the first lease product in every single country in the world. This product is invariably defined by the lessees intend to own the equipment at the end. The lease is solely a financing instrument. When the lease term comes to end, the lessee who has fully paid the lessor by the lease rentals owns the equipment for a nominal amount (Amembal, 2000).

The psychology behind ownership is still very much inherent in the users mind process, since leasing is a new product. The lessor, too, aims to merely finance the equipment purchases by a lease and is not inclined to have the asset returned at the end of the term.

For the lessor, credit risk, not asset risk, is acceptable, as the latter requires a developed secondary market that does not exist during this stage. The lease product is almost invariably offered on a net basis in which the lessor's services are limited to financing the equipment.

During this stage the market is commonly rate driven and not "value add" driven. However, lessors who have rates that are not inevitably market competitive are capable of surviving as the lessors with better rates have a capacity problem. Bangladesh, Croatia, Honduras, and Romania are the countries included in this phase (Amembal, 2011).

\subsubsection{The Creative Finance Lease stage}

During this stage, lessors start structuring many of their finance leases and also provide the lessee with different types of end-of-term options such as the option to renew according to a fixed residual, (the lessee must either purchase or renew). In most countries during this phase, the largest growth is experienced leasing, in terms of both market penetration and absolute volume. Also, many vendors/manufacturers that previously relied on independent leasing companies, start forming their own leasing companies (Tourick, 2002). Tax authorities and regulators who realize the importance of leasing, look at the industry closely and come to regulations, rules, and guidelines, meant to stimulate further growth (Miri \& Habibi, 2007). Often times, however, the actions are directed at curbing tax abuses such as those caused by the very short-term "Norwegian" leases.

This phase, too, is generally rate concentrated although some lessors, according to severe competition, start addressing the value added aspects of leasing (Amembal, 2011). These aspects may consist of shortening the response time from the date of lease application to the date of lease funding or bundling of services, for example, maintenance, into the finance lease (Beattie, et al., 2006).

While the market is faced with substantial growth, rate-focused leasing at times results in volume competition. Lessors start narrowing their spreads in a buyer's market (Amembal, 2000). Continued narrowing of spreads makes many lessors exit the industry as evidenced in some countries like India and Korea which has recently experienced. The industry learns from experience that it cannot remain rate driven. Guatemala, India, Pakistan, panama, Peru, and Portugal are examples of countries in stage three (Amembal, 2011).

\subsubsection{The Operating Lease Stage}

Coming about with the passage of time, multinational lessees and developing or developed secondary markets have demanded an intense competition, and transfer of technology from one leasing country to another. In some countries, like Mexico, the product is fueled by the fact that finance leases are denied "true lease" or "tax lease" status. In many countries, by the introduction of accounting rules that moves the country from form to substance, the demand for operating leases offer off balance sheet financing to the lessee is developed (Amembal, 2000, 2011).

The key traits of this product are the capability of the lessee to return the equipment at the end of the lease term and full - service nature of many operating leases. Bundling and one- stop-shopping become a convenience to the lessee. With these characteristics, (for example using computers), software, hardware, maintenance, installation, and training are packaged into one transaction.

In this stage, unconnected to the operating lease product, the lessee comes to be an astute, complicated player as leasing has become more and more acceptable as an extremely viable financial product. Therefore, language in lease contracts is not unilaterally drafted by the lessor, but is carefully negotiated; in fact, always, lessees want to utilize master leases drafted by their own legal counsel.

\subsubsection{The New Products stage}

In this stage, the operating lease becomes too sophisticated, with complex end-of-term options (such as puts, 
calls, and first amendment clauses), early termination options, upgrades and rollovers, technology refreshes, and the like. Phase Five creates new products such as synthetic leases, venture leases, and securitization (off balance sheet loans). Some of the western European countries and Australia are countries included in this phase. The industry, finally, following the classic industry curve from infancy to maturity, enters the last stage (Amembal, 2011).

\subsubsection{Maturity}

Substantial consolidation characterizes Maturity within the industry. Such consolidation takes the form of mergers, joint ventures/alliances, acquisitions, and equity roll-ups (the latter one recently seen in the US). Moreover maturity brings forth lower margins, causing lessors to expect profits via operational efficiencies as for increased sales volume. Penetration expands in this stage, as leasing volume gets bigger only with the overall growth of the economy (Amembal, 2007).

Although the six stages apply universally, it is significant to note two points. In the one hand, the sequence applies to the industry in general within each country, and not to all of the players. It is really popular for lessors not to grow sequentially. Some that offer new Products such as venture leases may not be in the operating lease business. On the other hand, each phase is not mutually exclusive (Williamson, et al., 1992).

By considering these phases, Iran is in the transition level from phase II to phase III. In order to complete this level, it is essential to have flexibility in lease processes especially lease rental calculation.

Leasing companies and other financial institutes employ Simple Bank Method in Iran from the emerging time till year 1387 Banks, but now PMT method is used in the calculation of rentals.

\section{Methodology}

The comparison between the simple bank method and the PMT method in the calculation of loan.

\subsection{The simple bank method}

In this method the interest is first calculated, and then the principal is added to it. The result is divided by the number of installments. This way each installment is calculated. This is shown below:

$$
\begin{gathered}
\text { loan interest }=\frac{\text { amount of loan } \times(\text { payback period }+1) \times \text { interest rate }}{2400} \\
\text { amount of each installment }=\frac{\text { loan principal }+ \text { loan interest }}{\text { number of installments }}
\end{gathered}
$$

\subsection{PMT method}

In this method each installment is first calculated and then the amount of each installment is multiplied by the number of installments. This way interest and principal can be identified.

$$
\mathrm{A}=\mathrm{C} \times\left[\frac{(1+\mathrm{r})^{\mathrm{n}} \times \mathrm{r}}{(1+\mathrm{r})^{\mathrm{n}}-1}\right] \begin{aligned}
& \mathrm{A}=\text { amount of each installment } \\
& \mathrm{C}=\text { Amount of loan } \\
& \mathrm{r}=\text { monthly rate } \\
& \mathrm{n}=\text { number of installments }
\end{aligned}
$$

loan interest and principal $=\mathrm{A} \times$ number of installments

\subsection{Identification of principal and interest for each installment}

\subsubsection{The simple bank method}

In this method the principal and interest are calculated on the basis of interest and the number of years of the loan.

$$
\text { Interest on each installment }=\text { Amount of loan } \times \frac{\text { Installment number }}{\frac{\mathrm{n}(\mathrm{n}+1)}{2}}
$$

Number of installments $=\mathrm{n}$

Amount of loan=loan interest and principal - interest on installment 


\subsubsection{The PMT method}

This is shown below:

$$
\text { interest on each installment }=\text { loan balance } \times \text { monthly rate }
$$

The difference between the two methods and their strong and weak points are explained in an example below:

Example: Suppose somebody obtains $1,000,000 \$$ in finance for a period of 10 years at the rate of 24 per cent. The calculation is as follows:

\subsection{The simple bank method}

$$
\begin{gathered}
\text { Amount of interest }=\frac{1.000 .000 \times 121 \times 24}{2400}=1.210 .000 \\
\text { Amount of each installment }=\frac{1.000 .000+1.210 .000}{120}=18.417
\end{gathered}
$$

\subsection{The PMT method}

$$
\text { Amount of each installment }=1.000 .000 \times\left[\frac{\left(1+\frac{24}{1200}\right)^{120} \times \frac{24}{1200}}{\left(1+\frac{24}{1200}\right)^{120}-1}\right]=22.048
$$

Loan interest and principal $=22.048 \times 120=2.645 .770$

Amount of loan interest $=2.645 .770-1.000 .000=1.645 .770$

Calculation of interest in the bank and PMT methods is given in the Table 1.

\subsection{A comparison between the two methods}

- Installment is bigger in the PMT than in the simple bank method.

- Because in the bank method installments are divided into principal and interest based on the amount of interest, if the number or amount of installments is high, interest will be larger than the principal and as a result, the principal will be negative.

- Since in the PMT method installments are divided on the basis of the finance amount, the principal will never be negative.

- Since in the division of each installment into the principal and interest the amount of principal is higher in the PMT method than in the simple bank method, if the customer wants to settle his debt in the first years, the remaining amount of the finance for settlement will be lower (especially when the period is longer or the rate of the facilities higher).

\section{Calculation of the stepped method (up method - down method)}

As stated earlier, leasing has played an important role in the economic cycle of each country. Leasing has also pursued customer-centered policies in each country. One of the problems of the customers is paying back the installments in the first years due to their low income; this policy offers the stepped method to customers to solve the problem. They will pay smaller initial installments and as their income rise in the following years, they will be able to pay larger amount of installments. And vice versa, if the income is higher in the first years, decreasing during the following years, like in case of industrial machinery, the amount of installment will change from higher to lower.

This method has another advantage of reducing the lessor's bad debts and that is because of customers' ability to pay the small initial installments on time and this, in the long run, will make customers become accustomed to paying back their installments.

\subsection{Step up method}

In this method initial installments will be small and they will increase incrementally toward the end of the period, and because the principal will not be negative, the first installment in the first step will be the amount of interest and the amount of the installment hence the amount of the first step cannot be smaller than the interest amount (As shown in Table 2). 


\subsubsection{Advantages are as follows}

- Since the customer is only able to pay smaller installments in the first years, this method will help them to pay their debts in due time.

- The leasing company will have an increase in its debt recovery and this is one of the important indicators for the company.

- The total amount of the principal and interest will be larger in this method than in the simple method.

4.1.2. Disadvantages are as follows:

- The low amount of the initial installments will mean lower cash for the company hence a lower ability of the company for its presence in the market.

- A lower cash for the company in the first years will cause the company to lose its opportunities in the market.

\subsection{Step down method}

This method will be well applicable to machineries and vehicles that are depreciable and generate income. The reason for this is that the depreciation and maintenance costs are low; as a result the customer will be better able to pay its installments. As the maintenance and depreciation costs increase, the amount of the installments will decrease and the customer will be able to pay its installments.

In this method the amount of installments in the first years is higher and will decrease toward the end of the period in accordance with the number of installments (As shown in Table 3).

4.2.1 Advantages are as follows

- In this method the amount of installments will be in accordance with customer income.

- The company will enjoy a higher cash and financial ability in the first years and will avail itself of the re-investment opportunities.

- Pay back of the large portion of the facilities in the first years will enable the customer to have an early settlement of the debt.

4.2.2 Disadvantages are as follows

- Lack of customer interest in this method.

- The higher possibility of bad debts.

\section{Conclusion and Suggestions Remarks}

1) Investment return is higher in PMT than in the bank method.

2) In the PMT method and at the time of early settlement the settlement amount is lower than the amount of facilities obtained.

3) Using the step up method results in investment development and customer satisfaction.

4) Using the step down brings about an enhancement of the cash position of the company and allows the company to make use of the re-investment opportunities available in the market.

5) The simple bank method is not recommended for reasons of decrease in investment return.

6) The stepped method (step up) is recommended for the expansion of investment in the market with customer-centeredness as a goal.

7) The step down method is recommended for investments in the rentals of machineries and heavy vehicles.

\section{References}

Amembal, S. (2000). International Leasing The Complete Guide (Vol. I \& II). American Power Conservation.

Amembal, S. (2006). Euromoney Yearbooks parts of Euromoney Institutional Investors PLC. [Online] Available: http://www.euromoneyplc.com/

Amembal, S. (2007). Winning With Leasing. Amembal \& Associates.

Amembal, S. (2011). Leasing's Evolution. A Guide to Strategic Decision Making. [Online] Available: www.globalleasingresource.com

Beattie, V., Goodacre, A., \& Thomson, S. J. (2006). International lease-accounting reform and economic 
consequences: The views of U.K. The International Journal of Accounting, 41(1), 75-103. http://dx.doi.org/10.1016/j.intacc.2005.12.003

FASB. (2008). Accounting for leases: FASB statement no. 13 as amended and interpreted through May 1980: incorporating statements 13, 17, 22, 23, 26, 27, $28 \& 29$, and interpretations 19, 21, 23, 24, $26 \& 27$. Financial Accounting Standards Board.

Miri, H. (2006). Industry \& Mine Leasing Co. Paper presented at the A collection of articles and lectures in the first conference on leasing industry (opportunities and challenges), Iran.

Miri, H., \& Habibi, P. (2007). Leasing Companies Society of Iran. Tehran: Samari Publication.

Williamson, J., \& Lybraud, D. (1992). Lease Accounting in The U.K.

Table 1. Calculation of interest in the bank and PMT methods

\begin{tabular}{|c|c|c|c|c|c|c|c|c|}
\hline \multirow{3}{*}{$\begin{array}{l}\text { Number of } \\
\text { installment }\end{array}$} & \multicolumn{4}{|c|}{ Equal installments bank method } & \multicolumn{4}{|c|}{ Equal installments PMT method } \\
\hline & \multirow{2}{*}{$\begin{array}{c}\text { Principal } \\
\text { balance }\end{array}$} & \multicolumn{3}{|c|}{ Amount of each installment } & \multirow{2}{*}{$\begin{array}{c}\text { Principal } \\
\text { balance }\end{array}$} & \multicolumn{3}{|c|}{ Amount of each installment } \\
\hline & & Interest & Principal & Total & & Interest & Principal & Total \\
\hline 1 & $1,000,000$ & 20,000 & $-1,583$ & 18,417 & $1,000,000$ & 20,000 & 2,048 & 22,048 \\
\hline 2 & 1.001 .583 & 19.833 & 417 & 18.417 & 997.952 & 59 & 2.089 & 22.048 \\
\hline 3 & 003.000 & 19.667 & -1.250 & 18.417 & 995.863 & 19.917 & 2.131 & 22.048 \\
\hline 4 & 1.004 .250 & 19.500 & -1.083 & 18.417 & 993.732 & 19.875 & 2.173 & 22.048 \\
\hline 5 & 1.005 .333 & 19.333 & -917 & 18.417 & 991.559 & 19.831 & 2.217 & 22.048 \\
\hline 6 & 1.006 .250 & 19.167 & -750 & 18.417 & 989.342 & 19.787 & 2.261 & 22.048 \\
\hline 7 & 1.007 .000 & 19.000 & -583 & 18.417 & 987.080 & 19.742 & 2.306 & 22.048 \\
\hline 8 & 007.583 & 18.833 & -417 & 18.417 & 984.774 & 19.659 & 2.353 & 22.048 \\
\hline 9 & 1.008 .000 & 18.667 & -250 & 18. & 982.421 & 19.648 & 2.400 & 22.048 \\
\hline 10 & 1.008 .250 & 18.500 & -83 & 18. & 980.022 & 19.600 & 2.448 & 22.048 \\
\hline 11 & 1.008 .333 & 18.333 & 83 & 18.417 & 977.574 & 19.551 & 2.497 & 22.048 \\
\hline 12 & 1.008 .250 & 18.167 & 250 & 18.417 & 975.077 & 19.504 & 2.547 & 22.048 \\
\hline
\end{tabular}

Table 2. Comparison calculation of interest between equal installments and step up method in PMT

\begin{tabular}{|c|c|c|c|c|c|c|c|c|}
\hline \multirow{2}{*}{$\begin{array}{c}\text { Number of } \\
\text { installment }\end{array}$} & \multicolumn{4}{|c|}{ Step up method } & \multicolumn{3}{c|}{ Interest with equal installments (PMT) } \\
\cline { 3 - 5 } & Principal & \multicolumn{2}{|c|}{ Amount of each installment } & Principal & \multicolumn{2}{|c|}{ Amount of each installment } \\
\cline { 9 - 11 } & balance & Interest & Principal & Total & balance & Interest & Principal & Total \\
\hline 1 & $1,000,000$ & 20,000 & 0 & 20,000 & $1,000,000$ & 20,000 & 2,048 & 22,048 \\
\hline 2 & 1.000 .000 & 20.000 & 0 & 20.000 & 997.954 & 19.959 & 2.089 & 22.048 \\
\hline 3 & 1.000 .000 & 20.000 & 0 & 20.000 & 995.893 & 19.917 & 2.131 & 22.048 \\
\hline 4 & 1.000 .000 & 20.000 & 0 & 20.000 & 993.732 & 19.875 & 2.173 & 22.048 \\
\hline 5 & 1.000 .000 & 20.000 & 0 & 20.000 & 991.559 & 19.831 & 2.217 & 22.048 \\
\hline 6 & 1.000 .000 & 20.000 & 0 & 20.000 & 989.342 & 19.787 & 2.261 & 22.048 \\
\hline 7 & 1.000 .000 & 20.000 & 0 & 20.000 & 987.080 & 19.742 & 2.306 & 22.048 \\
\hline 8 & 1.000 .000 & 20.000 & 0 & 20.000 & 984.774 & 19.695 & 2.353 & 22.048 \\
\hline 9 & 1.000 .000 & 20.000 & 0 & 20.000 & 982.421 & 19.648 & 2.400 & 22.048 \\
\hline 10 & 1.000 .000 & 20.000 & 0 & 20.000 & 980.022 & 19.600 & 2.448 & 22.048 \\
\hline 11 & 1.000 .000 & 20.000 & 0 & 20.000 & 977.574 & 19.551 & 2.497 & 22.048 \\
\hline 12 & 1.000 .000 & 20.000 & 0 & 20.000 & 975.077 & 19.502 & 2.547 & 22.048 \\
\hline 2nd year & 1.000 .000 & 19.828 & 877 & 20.705 & 972.451 & 19.451 & 2.597 & 22.048 \\
\hline 3rd year & 990.543 & 19.426 & 2.019 & 21.435 & 937.693 & 18.754 & 3.294 & 22.048 \\
\hline 4th year & 968.758 & 18.690 & 3.500 & 22.190 & 893.510 & 17.870 & 4.178 & 22.048 \\
\hline 5th year & 930.995 & 17.560 & 5.413 & 22.973 & 837.476 & 16.750 & 5.298 & 22.048 \\
\hline 6th year & 872.610 & 15.911 & 7.872 & 23.783 & 766.411 & 15.328 & 6.720 & 22.048 \\
\hline 7th year & 787.700 & 13.595 & 11.026 & 24.621 & 676.284 & 13.525 & 8.523 & 22.048 \\
\hline 8th year & 668.768 & 10.427 & 15.026 & 25.489 & 561.980 & 11.240 & 10.808 & 22.048 \\
\hline 9th year & 506.291 & 6.167 & 20.221 & 26.388 & 417.016 & 8.340 & 13.708 & 22.048 \\
\hline 10th year & $288 / 178$ & 518 & 26.800 & 27.318 & 233.166 & 4.663 & 1 & 22.048 \\
\hline
\end{tabular}


Table 3. Comparison between step down method and step up method in PMT

\begin{tabular}{|c|c|c|c|c|c|c|c|c|}
\hline \multirow{3}{*}{$\begin{array}{l}\text { Number of } \\
\text { installment }\end{array}$} & \multicolumn{4}{|c|}{ Step down method } & \multicolumn{4}{|c|}{ Step up method } \\
\hline & \multirow{2}{*}{$\begin{array}{c}\text { Principal } \\
\text { balance }\end{array}$} & \multicolumn{3}{|c|}{ Amount of each installment } & \multirow{2}{*}{$\begin{array}{c}\text { Principal } \\
\text { balance }\end{array}$} & \multicolumn{3}{|c|}{ Amount of each installment } \\
\hline & & Interest & Principal & Total & & Interest & Principal & Total \\
\hline 1 & $1,000,000$ & 20,000 & 7,000 & 27,000 & $1,000,000$ & 20,000 & 0 & 20,000 \\
\hline 2 & 993.000 & 19.860 & 7.140 & 27,000 & $1,000,000$ & 20,000 & 0 & 20000 \\
\hline 3 & 985.860 & 19.717 & 7.282 & 27,000 & $1,000,000$ & 20,000 & 0 & 20,000 \\
\hline 4 & 978.577 & 19.572 & 7.428 & 27,000 & $1,000,000$ & 20,000 & 0 & 20,000 \\
\hline 5 & 971.148 & 19.423 & 7.577 & 27,000 & $1,000,000$ & 20,000 & 0 & 20,000 \\
\hline 6 & 963.571 & 19.271 & 7.728 & 27,000 & $1,000,000$ & 20,000 & 0 & 20,000 \\
\hline 7 & 955.843 & 19.117 & 7.883 & 27,000 & $1,000,000$ & 20,000 & 0 & 20,000 \\
\hline 8 & 947.960 & 18.959 & 8.041 & 27,000 & $1,000,000$ & 20,000 & 0 & 20,000 \\
\hline 9 & 939.919 & 18.798 & 8.202 & 27,000 & $1,000,000$ & 20,000 & 0 & 20,000 \\
\hline 10 & 931.717 & 18.634 & 8.366 & 27,000 & $1,000,000$ & 20,000 & 0 & 20,000 \\
\hline 11 & 923.351 & 18.467 & 8.533 & 27,000 & $1,000,000$ & 20,000 & 0 & 20,000 \\
\hline 12 & 914.818 & 18.296 & 8.704 & 27,000 & $1,000,000$ & 20,000 & 0 & 20,000 \\
\hline 2nd year & 906.115 & 16.481 & 8.383 & 24.864 & $1,000,000$ & 19.828 & 877 & 20.705 \\
\hline 3rd year & 815.685 & 14.711 & 8.187 & 22.898 & 990.543 & 19.416 & 2.019 & 21.465 \\
\hline 4 th year & 727.370 & 12.955 & 8.132 & 21.087 & 968.758 & 18.690 & 3.500 & 22.190 \\
\hline 5th year & 639.654 & 11.180 & 8.239 & 19.419 & 930.995 & 17.560 & 5.413 & 22.973 \\
\hline 6th year & 550.775 & 9.344 & 8.540 & 17.884 & 872.610 & 15.911 & 7.874 & 23.783 \\
\hline 7th year & 458.654 & 7.397 & 9.072 & 16.469 & 787.700 & 13.595 & 11.026 & 24.621 \\
\hline 8th year & 360.790 & 5.281 & 9.886 & 15.167 & 668.768 & 10.427 & 15.062 & 25.489 \\
\hline 9th year & 254.145 & 2.920 & 11.047 & 13.967 & 506.291 & 6.167 & 20.221 & 26.388 \\
\hline 10th year & 134.980 & 226 & 12.637 & 12.863 & 288.178 & 518 & 26.800 & 27.318 \\
\hline
\end{tabular}

Appendix. Comparison between the simple bank method and the PMT method

\begin{tabular}{|c|c|c|}
\hline & Bank method & PMT method \\
\hline Amount of loan & 1.000 .000 & 1.000 .000 \\
\hline Annual interest rate & $24 \%$ & $24 \%$ \\
\hline Monthly interest rate & $2 \%$ & $2 \%$ \\
\hline The number of installments & 120 & 120 \\
\hline Interest & 1.210 .000 & 1.654 .770 \\
\hline Principal and interest & 2.210 .000 & 2.645 .770 \\
\hline Amount of each installment & 18417 & 22048 \\
\hline
\end{tabular}

